\title{
Penerapan Blended Learning dengan Whatsapp untuk Meningkatkan Pemahaman Konsep Pada Materi Kelistrikan di SMK Negeri 2 Kendari
}

\author{
Nur Fadhilah Asdar ${ }^{1 *}$, Arisona ${ }^{2)}$, Rosliana Eso ${ }^{3)}$ \\ 1)*Mahasiswa Jurusan Pendidikan Fisika FKIP UHO, Kendari, Sulawesi Tenggara, Indonesia 93232 \\ ${ }^{2)}$ Dosen Jurusan Teknik Geologi FTIK UHO, Kendari, Sulawesi Tenggara, Indonesia 93232 \\ ${ }^{3)}$ Dosen Jurusan Pendidikan Fisika FKIP UHO, Kendari, Sulawesi Tenggara, Indonesia 93232
}

*Korespondensi E-mail: nur.fadhilah251@gmail.com

\begin{abstract}
The aim of study is to investigate the impact whatsapp-blended learning implementation of SMKN 2 Kendari student's understanding of electricity learning. The study is quantitative research with pre-experimental way while using one group pretest-posttest design of research. Moreover, a research sample is taken by the method of probability sampling which is kind of simple random sampling. A technique of data collecting uses to test and non-test (questioner). A technique of data analysis uses descriptive statistic and inferential statistic. The results of this study show that the average value of student's abilities to understand the physic concept on pre-test which is representatively 43.72, while in the post-test it is 88.00 while in the post-test it is 88.00 with an average n-gain of 0.78. The study shows that blended learning application generally takes a great response of students, which stood on $64.48 \%$ of the average scores.
\end{abstract}

Keywords: Blended Learning; WhatsApp; Ability to comprehend the concept

Abstrak: Tujuan penelitian ini adalah untuk mengetahui pengaruh penerapan blended learning berbantuan whatsapp terhadap kemampuan pemahaman konsep peserta didik pada materi kelistrikan di SMK Negeri 2 Kendari. Penelitian ini merupakan penelitian kuantitatif dengan jenis pre-experimental, desain penelitian one group pretest-posttest design. Pengambilan sampel dilakukan dengan teknik probability sampling dengan jenis simple random sampling. Teknik pengumpulan data dalam penelitian ini menggunakan tes dan non tes (kuesioner). Teknik analisis data menggunakan statistik deskriptif. Hasil penelitian ini menunjukkan bahwa: kemampuan pemahaman konsep fisika peserta didik pada pretest bernilai rata-rata 43.72 sedangkan kemampuan pemahaman konsep fisika peserta didik pada posttest sebesar 88.00 dengan rata-rata $n$-gain sebesar 0.78 . Hasil respon peserta didik terhadap penerapan blended learning sebagian besar peserta didik memberikan respon positif, hal ini dapat dilihat dari perolehan persentase nilai rata-rata sebesar $64.48 \%$.

Kata Kunci: Blended learning; Whatsapp; Kemampuan Pemahaman Konsep

\section{PENDAHULUAN}

Perkembangan teknologi membawa perubahan dalam berbagai bidang salah satu diantaranya dalam bidang ilmu pengetahuan dan teknologi (IPTEK). Hal ini menyebabkan perubahan paradigma proses pembelajaran yang ditandai dengan perubahan kurikulum, media dan teknologi. Prinsip pembelajaran pada abad 21 memungkinkan ketercapaian dari sistem pendidikan atau proses pembelajaran yang baik khususnya pada mata pelajaran fisika. Untuk mencapai tujuan pembelajaran khusunya pada mata pelajaran fisika maka diperlukan suatu pembelajaran yang sesuai dengan perkembangan abad 21 .
Blended learning merupakan model pembelajaran yang dapat meningkatkan daya tarik pada proses pembelajaran tatap muka (face-to-face) dan sangat sesuai untuk diterapkan di era 21 (Munir 2017:65). Proses pemanfaatan teknologi dalam pembelajaran biasa disebut e-learning (elektronic learning), memberikan lingkungan belajar yang berbeda. Berdasarkan penelitian yang dilakukan oleh Walib Abdullah (2018) mengatakan bahwa pembelajaran yang memadukan antara e-learning dan tatap muka (konvensional) atau biasa disebut blended learning mempunyai pengaruh yang tinggi dibandingkan dengan pembelajaran online/tatap muka karena blended learning mampu mengatasi kelemahan yang 
dihadapi dalam pembelajaran langsung ataupun pembalajaran online. Perlu diketahui juga bahwa proses pembelajaran mengandung lima komponen komunikasi yaitu guru (komunikator), peserta didik (komunikan), bahan pembelajaran, tujuan pembelajaran dan media pembelajaran. Media pembelajaran dapat membantu pendidik menyajikan informasi menjadi lebih menarik. Salah satu media yang dapat digunakan dalam proses belajar mengajar adalah smartphone. Penggunaan smartphone tentu tak asing bagi peserta didik. Survei yang dilakukan oleh Irwandani tahun 2016 hampir 98\% peserta didik memiliki akun sosial media dan $94 \%$ peserta didik menggunakan internet dalam menyelesaikan tugas sekolahnya. platform berupa whatsapp dapat menjadi salah satu pilihan yang dapat digunakan sebagai virtual classroom (Sholihatin, 2019). Dalam pelaksanan proses belajar mengajar, pengajar merupakan sumber belajar utama dirasa tidak cukup lagi, tetapi perlu dilengkapi sumber belajar lainnya. Sumber belajar pengajar harus terintegrasi dengan sumber belajar lain, yaitu sumber belajar cetak, audio, audio visual, dan komputer. Bahkan bisa memanfaatkan mobile learning, seperti handphone/ smartphone. Diperlukan pengetahuan, sikap, dan keterampilan pengajar dalam merancang pembelajaran terutama dalam upaya memecahkan masalah atau mengaplikasikannya dalam rancangan pembelajaran agar kualitas pembelajaran meningkat. Hal ini juga perlu dilaksana dalam proses pembelajaran fisika. Salah satu penyebab penguasaan konsep fisika yang lemah dikarenakan pengajar selama pembelajaran lebih banyak memberi ceramah atau penyampaian produk saja, maka peserta didik kurang terlatih untuk mengembangkan daya berpikir dalam pengaplikasian konsep yang telah dipelajari. Kegiatan pembelajaran seperti ini dapat memberi dampak negatif bagi peserta didik terutama terhadap kemampuan fisikanya berupa pemahaman konsep.

Salah satu kecakapan dalam pembelajaran fisika yang perlu dimiliki oleh peserta didik adalah pemahaman konsep. Menurut Kilpatrick, Swafford \& Findell pemahaman konsep (conceptual understanding) adalah kemampuan dalam memahami konsep, teori, dan operasi matematis dalam fisika. Bloom juga mengatakan pemahaman konsep adalah kemampuan menangkap pengertian-pengertian seperti mampu mengungkapkan suatu materi yang disajikan kedalam bentuk yang lebih dipahami maupun memberikan interpretasi dan mampu mengaplikasikannya (Hamdani, 2012). Kemampuan memahami konsep menjadi landasan untuk berpikir dalam menyelesaikan berbagai persoalan. Pesrta didik dikatakan memahami bila mereka dapat mengkontruksi makna dari pesan-pesan pembelajaran, baik yang bersifat lisan, tulisan ataupun grafis yang disampaikan melalui pengajaran, buku atau layar komputer (Anderson dan Krathwohl, 2001).

Berdasarkan hasil observasi di SMK Negeri 2 Kendari ditemukan bahwa guru belum pernah melaksanakan pembelajaran blended learning, pembelajaran yang dilakukan masih bersifat centered learning serta terdapat konsep-konsep pembelajaran yang tidak hanya cukup disampaikan secara verbal namun harus diwujudkan dalam bentuk virtual, serta terbatasnya jam pembelajaran disekolah menyebabkan kurang efektifnya pemberian materi di ruang kelas. Maka diperlukan suatu desain pembelajaran yang sesuai dengan permasalahan yang dihadapi sekolah berupa penggunaan blended learning.

Berdasarkan uraian tersebut, maka peneliti perlu melakukan penelitian tentang "Penerapan Blended Learning dengan Whatsapp untuk Meningkatkan Pemahaman Konsep Pada Materi Kelistrikan di SMK Negeri 2 Kendari" Tujuan penelitian ini adalah untuk mengetahui penerapan blended learning berbantuan whatsapp terhadap peningkatan kemampuan pemahaman konsep peserta didik.

\section{METODE}

Metode yang digunakan dalam penelitian ini adalah metode eksperimen. Bentuk penelitian yang digunakan dalam penelitian ini pre-eksperimental. Berdasarkan bentuk penelitian maka digunakan rancangan one group pretest-posttest. Seperti yang ditunjuk pada Tabel 1. Dalam penelitian ini hanya menggunakan satu kelompok sampel.

Tabel 1. Desain Penelitian

\begin{tabular}{cccc}
\hline Kelompok & Pre-Test & Treatment & Post Test \\
\hline Eksperimen & $\mathrm{O}_{1}$ & $\mathrm{X}$ & $\mathrm{O}_{2}$ \\
\hline
\end{tabular}

Populasi dalam penelitian ini adalah peserta didik kelas X jurusan Teknik Instalasi Tenaga Listrik SMK Negeri 2 Kendari tahun ajaran 2019/2020 yang terdiri dari tiga kelas yang berjumlah 108 peserta didik. Sampel dalam penelitian ini diambil melalui teknik probability sampling dengan jenis simple random 
sampling. Adapun sampel dalam penelitian ini adalah kelas X TITIL $_{\mathrm{B}}$.

Teknik pengumpulan data dilakukan dengan menggunakana teknik tes dan non-tes. Tes yang digunakan adalah tes awal (pre-test) dan tes (post-test) yang bertujuan untuk melihat tingkat pemahaman konsep peserta didik sebelum dan sesudah diberikan perlakuaan menggunakan blended learning berbantuan whatsapp. Non-tes yang digunakan adalah kuesioner (angket) yang bertujuan untuk melihat respon peserta didik terhadap penerapan model blended learning menggunakan whatsapp dalam proses belajar mengajar.

Instrumen dalam penelitian ini adalah instrumen tes pemahaman konsep peserta didik yang mencakup soal-soal pada ranah kognitif $\mathrm{C} 2$ pada materi kelistrikan dalam bentuk soal essay. Dalam penelitian ini juga menggunakan kuesioner (angket) yang menggunakan skala likeart dengan 5 skala yang terdiri dari pernyataan positif dan negatif. Dalam skala likert, pernyataan-pernyataan yang diajukan, baik pernyataan positif maupun negatif, dinilai oleh subjek dengan sangat setuju, setuju, tidak punya pendapat, tidak setuju, sangat tidak setuju.

\section{HASIL PENELITIAN \\ Deskriptif Kemampuan Pemahaman Konsep}

Hasil analisis deskriptif digunakan untuk mendeskripsikan atau menggambarkan data yang telah terkumpul. Deskripsi data berasal dari hasil pretest dan post-test yang diberikan pada kelas eksperimen yang berjumlah 29 peserta didik. Pengolahan data seperti pada tabel berikut ini:

Tabel 2. Statistik Deskriptif Kemampuan Pemahaman Konsep

\begin{tabular}{cccc}
\hline Nilai & Pre-test & Post-test & N-Gain \\
\hline Minimum & 28 & 72 & 0.53 \\
\hline Maximum & 56 & 100 & 1.00 \\
\hline Rata-rata & 43.72 & 88.00 & 0.78 \\
\hline Std. Deviasi & 8.276 & 5.657 & 0.11 \\
\hline
\end{tabular}

\section{Hasil Pemerolehan Nilai Tes Kemampuan Pemahaman Konsep Peserta Didik Kelas Eksperimen}

Hasil tes kemampuan pemahaman konsep (C2) pada penelitian ini berdasarkan pada Taksonomi Bloom Anderson dan Krathwol, yaitu berupa

menafsirkan (interpreting), memberi contoh (exemplifying), mengklasifikasikan (classifying), menarik inferensi (inferring), membandingkan (comparing) dan menjelaskan (explaining). Perbandingan skor pencapaian indikator dapat dilihat pada Tabel 3.

Tabel 3. Perbandingan Nilai Indikator Tes Kemampuan Pemahama Konsep Pre-test dan Post-test

\begin{tabular}{|c|c|c|c|c|c|c|c|c|}
\hline \multirow{3}{*}{ No } & \multirow{3}{*}{$\begin{array}{c}\text { Indikator } \\
\text { Pemahaman } \\
\text { Konsep }\end{array}$} & \multirow{3}{*}{$\begin{array}{l}\text { Skor } \\
\text { Ideal }\end{array}$} & \multicolumn{6}{|c|}{ Skor Ideal } \\
\hline & & & \multicolumn{3}{|c|}{ Pre-test } & \multicolumn{3}{|c|}{ Post-test } \\
\hline & & & Skor & $\bar{x}$ & $\%$ & Skor & $\bar{x}$ & $\%$ \\
\hline 1 & Menafsirkan & 116 & 63 & 0.54 & 54.31 & 103 & 0.89 & 88.79 \\
\hline 2 & Memberi contoh & 116 & 92 & 0.79 & 79.31 & 107 & 0.92 & 92.24 \\
\hline 3 & Mengklasifikasikan & 116 & 108 & 0.93 & 93.10 & 116 & 1.00 & 100.0 \\
\hline 4 & Menarik inferensi & 116 & 54 & 0.47 & 46.55 & 92 & 0.79 & 79.31 \\
\hline 5 & Membandingkan & 145 & 0 & 0 & 0 & 118 & 0.81 & 81.38 \\
\hline 6 & Menjelaskan & 116 & 0 & 0 & 0 & 102 & 0.88 & 87.93 \\
\hline
\end{tabular}

Hasil perolehan nilai $N$-Gain yang dikonvernsi dari nilai pre-test dan post-test pada kelas eksperimen dapat dikelompokkan menjadi beberapa kategori berdasarkan klasifikasi tafsiran. Data dikelompokkan berdasarkan frekuensi banyaknya peserta didik yang memperoleh nilai $N$-Gain tertentu. Perhitungan frekuensi dilakukan agar diperoleh berapa banyak peserta didik yang termasuk dalam kategori efektif dibandingkan dengan keseluruhan data. Berikut ini adalah tabel pemerolehan $N$-Gain pada kelas eksperimen: 
Tabel 4. Daftar Kategori Tafsiran Efektivitas dan Frekuensi Persentase N-Gain Kemampuan Pemahaman Konsep Kelas Peserta Didik

\begin{tabular}{llll}
\hline \multirow{2}{*}{ Persentase (\%) $\boldsymbol{N}$-Gain } & \multirow{2}{*}{ Tafsiran } & \multicolumn{2}{c}{ Kelas Eksperimen } \\
\cline { 3 - 4 } $\mathrm{g}<0.3$ & Rendah & 0 & $\mathbf{F})$ \\
\hline $0.3 \leq \mathrm{g} \leq 0.7$ & Sedang & 7 & 0 \\
\hline $0.7>\mathrm{g}$ & Tinggi & 22 & 24.14 \\
\hline
\end{tabular}

Berdasarkan Tabel 4 kategori Gain keterampilan berpikir kritis pada materi kelistrikan Sebagian besar peserta didik berada pada kategori tinggi yang berjumlah 22 peserta didik dengan persentase $75.86 \%$ dari jumlah peserta didik kelas eksperimen.

\section{Analisis Angket}

Hasil respon peserta didik terhadap pembelajaran model blended learning berbantuan whatsapp dapat dilihat pada Tabel 5 berikut ini.

Tabel 5. Respon Ketertarikan Peserta Didik terhadap Pembelajaran Model Blended Learning Berbantuan Whatsapp

\begin{tabular}{ccccccc}
\hline Indikator & Sinkronus & Ket & Asinkronus & Ket & Blended Learning & Ket \\
\hline Sikap & $69 \%$ & SB & $59.897 \%$ & SB & $64.45 \%$ & SB \\
\hline Minat & $76.5 \%$ & HS & $63 \%$ & SB & $69.75 \%$ & SB \\
\hline Pemahaman & $65 \%$ & SB & $53.33 \%$ & SB & $59.17 \%$ & SB \\
\hline $\begin{array}{c}\text { Rata-rata } \\
\text { Total }\end{array}$ & $70.17 \%$ & SB & $58.78 \%$ & SB & $64.48 \%$ & SB
\end{tabular}

*HS : Hampir Setengahnya

*SB : Sebagian Besar

Tabel 5 menunjukkan bahwa penerapan model blended learning berbantuan whatsapp dalam proses pembelajaran fisika pada materi kelistrikan (listrik statis dan listrik dinamis) sebagian besar peserta didik memberi tanggapan yang positif atau tertarik dengan nilai rata-rata $64.48 \%$. Hasil angket respon siswa terhadap penerapan model blended learning berbantuan whatsapp dapat dilihat secara visual pada Gambar 1 berikut ini.

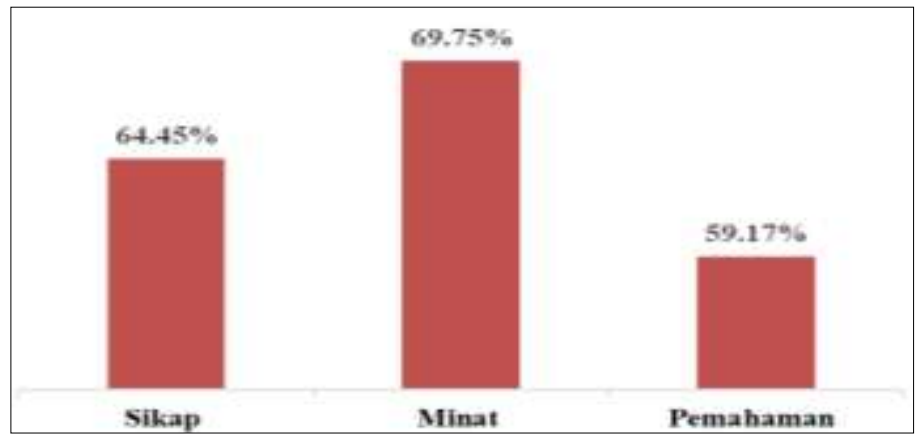

Gambar 1. Gambaran Angket Respon Siswa terhadap Model Blended Leaning Berbantuan Whatsapp

\section{PEMBAHASAN}

Berdasakan Tabel 2 kemampuan awal hasil tes belajar peserta didik kelas eksperimen masih rendah. Berdasarkan pencapaian rata-rata skor pretest yang diperoleh masih di bawah skor ideal. rata-rata skor pretest sebesar 0.66 kali skor ideal. Soal pre-test dan post-test yang digunakan merupakan instrumen untuk mengukur tingkat pemahaman konsep peserta didik.
Ada bebarapa hal yang menyebabkan rendahnya kemampuan awal hasil belajar peserta didik, diantaranya pendekatan pembelajaran yang tidak menekankan keterlibatan peserta didik secara individual personal, sehingga peserta didik tidak terpanggil untuk mempelajari fisika secara mendalam untuk mencapai hasil belajar yang maksimal. Kemudian, pembelajaran yang masih menerapkan 
metode konvensional belum dapat mengakomodir perbedaan individu terlebih lagi dengan jumlah peserta didik yang banyak dalam satu kelas, perhatian peserta didik yang terbatas serta muatan teori yang membutuhkan pemahaman mendalam. Sehingga proses pembelajaran cendrung berorientasi pada metode imposisi yaitu ketika pembelajaran berlangsung, guru hanya menyampaikan materi pelajaran dengan cara menuangkan hal-hal yang dianggap penting oleh guru bagi peseta didik.

Kemampuan akhir hasil tes kemampuan pemahaman konsep peserta didik mengalami peningkatan setelah diberikan perlakuan pembelajaran dengan menggunakan model blended learning berbantuan whatsapp. Kemampuan akhir hasil tes kemampuan pemahaman konsep peserta didik dapat dilihat dari hasil post-test yang menggunakan soal yang sama dengan pre-test. Hasil post-test menunjukka hasil tes kemampuan pemahaman konsep peserta didik mengalami peningkatan dari kemampuan awalnya. Dari hasil yang diperoleh tersebut dapat dilihat selisih rata-rata pre-test dan post-test sebesar 44.28 , hal ini menunjukkan bahawa pembelajaran blended learning berbantuan whatsapp dapat membantu peserta didik dalam proses belajar mengajar, sehingga kemampuan peserta didik untuk mengeuasai konsep yang dipelajari mengalami peningkatan. Peningkatan ini disebabkan oleh penggunaan model blended learning berbantuan whatsapp, saat proses pembelajaran yang memposisikan peserta didik sebagai subjek dan objek belajar serta dapat mengakomodir perbedaan individu. Pembelajaran model blended learning berbantuan whatsapp melibatkan peserta didik pada dua proses kegiatan pembelajaran yang dilalui, yaitu kegiatan asinkronus mandiri dan sinkronus langsung (face to face).

Hal serupa juga ditemukan pada hasil penelitian yang dilakukan oleh Herwanto (2013) mengatakan bahwa hasil tes pemahaman konsep yang diberikan juga mengalami peningkatan setelah diberikan perlakuan berupa penggunaan blended learning. Hal ini dikarenakan informasi yang diperoleh peserta didik lebih banyak dalam bentuk yang bermacam-macam dan selalu up to date. Senada dengan hal ini Weish dkk (2003) menyatakan bahwa blended learning mendukung keuntungan e-learning termasuk pengurangan biaya, efisiensi waktu dan kenyamanan tempat untuk pelajar dapat memahami pribadi dalam masalah penting dan dapat memberi motivasi saat pembelajaran langsung.

Selain itu, $75 \%$ peserta didik merasa mudah memahami konsep kelistrikan (listrik statis dan listrik dinamis) setelah menggunakan model blended learning. Hal ini sejalan dengan penelitian yang dilakukan oleh Suci Pratiwi Agustin (2019), yaitu pembelajaran yang terintegrasi teknologi mampu meningkatkan pemahaman konsep serta kemampuan pemecahan masalah peserta didik. Kemudian, peserta didik antusias dan tertarik mempelajari konsep kelistrikan (listrik statis dan listrik dinamis) selama proses pembelajaran. Hal tersebut terlihat dalam hasil angket repon peserta didik terkait pembelajaran model blended learning berbantuan Whatsapp yaitu sebesar $64.48 \%$, menunjukkan sebagian besar peserta didik tertarik dengan pembelajaran menggunakan model blended learning ini. Hal ini sejalan pula dengan penelitian dilakukan oleh Herwanto (2013) dan Syidiq Subagio (2019) mengatakan bahwa blended learning membuat penguasaan konsep dan penalaran fisika peseerta didik menjadi lebih baik. Dan penelitian yang dilakukan oleh Alfi (2015) dan Alam (2016) bahwa blended learning memberikan pengaruh positif dalam meningkatkan hasil belajar peserta didik. Hasil tersebut disebabkan blended learning merupakan model yang menggabungkan aspek positif dari pembelajaran tatap muka dan pembelajaran virtual. Aspek positif dari $e$ learning ialah memastikan fleksibilitas yang tidak dapat dijamin dalam pembelajaran tatap muka (pembelajaran yang tidak terbatas oleh ruang dan waktu) yang memungkinkan guru dan siswa melakukan pembelajaran yang lebih efektif (Kose, 2010), sedangkan aspek positif tatap muka adalah memungkinkan pembelajaran secara interaktif (Hadi, 2012) guru lebih mudah mengontrol keadaan kelas (Majid, 2013).

Pembelajaran model blended learning ini memiliki beberapa keterbatasan, diantaranya: 1) penelitian ini hanya diteliti pada materi listrik statis dan listrik dinamis, sehingga tidak dapat digeneralisasikan pada materi lain 2) pembelajaran dengan model blended learning membutuhkan akses internet yang stabil baik peserta didik maupun guru, sehingga harus mempunyai kuota internet yang memadai 3) pengontrolan terhadap kemampuan subjek penelitian hanya meliputi pembelajaran sinkronus langsung (face to face) pada variabel model blended learning dan hasil belajar peserta didik. Kegiatan asinkronus mandiri tidak sepenuhnya dikontrol, hanya menekankan pada sikap jujur peserta didik ketika memberikan keterangan sudah melakukan pembelajaran asinkronus mandiri.

\section{KESIMPULAN}

Berdasarkan hasil penelitian dan pembahasan maka dapat ditarik simpulan penelitian yaitu penerapan blended learning dengan menggunakan whatsapp yang ditinjau dari pemahaman konsep dapat dikatakan 
mengalami peningkatan pada materi kelistrikan di kelas X TITL B SMK Negeri 2 Kendari. Hal ini terbukti dari hasil tes pemahaman konsep dengan ratarata $n$-gain sebesar 0.78 dan berada pada kategori tinggi ( $>0.7$ ). dan Respon peserta didik terhadap penerapan blended learning berbantuan whatsapp dalam proses belajar mengajar memberikan tanggapan positif terhadap penerapan blended learning. Hal ini terlihat dari rata-rata angket peserta didik sebesar $64.84 \%$.

\section{DAFTAR PUSTAKA}

Abdullah, W 2018. Model Blended Learning dalam Meningkatkan Efektifitas Pembelajaran. Jurnal Pendidikan dan Manajemen Islam, Vol. 7, No. 1, hh. 855-866. DOI: https://doi.org/10.32806/jf.v7i1.3169.

Agustin, SP, 'Pengaruh Blended Learning Berbantuan Google Classroom Terhadap Hasil Belajar Siswa Sma Pada Konsep Gerak Lurus', Skripsi. Jakarta: Jurusan Pendidikan Ilmu Pengetahuan Alam Pada Fakultas Tarbiyah dan Keguruan UIN Syarif Hidayatullah.

Alam, U. D.; Syarifuddin \& Manurung, B 2016, Pengaruh Blended Learning Berbasis Edmodo \& Motivasi Belajar Terhadap Hasil Belajar IPA Biologi \& Retensi Siswa Pada Sistem Peredaran Darah Manusia Di Kelas VIII SMAN 5 Medan. Jurnal Pendidikan Biologi, Vol. 6, No. 1, hh. 260-266. DOI: $10.24114 /$ jpb.v6i1.4330.

Alfi, S. S 2015, 'Pengaruh Model Pembelajaran Blended Learning Terhadap Hasil Belajar Mata Pelajaran IPS Siswa Kelas 8 Di SMAN 36 Jakarta', Skripsi. Makassar: Jurusan Pendidikan Fisika Pada Fakultas Tarbiyah dan Keguruan UIN Alauddin Makassar.
Andersom, LW \& Krathwohl DR 2001, Kerangka Landasan Untuk Pembelajaran Pengajaran dan Asesmen, Yogyakarta, Pustaka Pelajar.

Hadi, B 2015, 'Pemanfaatan Aplikasi Whatsapp pada Pembelajaran Berbasis Blended Learning di SMK N 1 Sragen', Prosiding Workshop Nasional, hh. 36-44.

Herwanto, Kusairi, S \& Wartono 2013, 'Pengaruh Blended Learning terhadap Penguasaan Konsep dan Penalaran Fisika Peserta Didik Kelas X', Jurnal Pendidikan Fisika Indonesia, hh.67-76.

DOI: https://doi.org/10.15294/jpfi.v9i1.2582.

Kose, U 2010, 'A Blended Learning Model Suported With Web 2.0 Technologi', Jurnal Procedia Social \& Behavioral Sciences, Vol. 2, No. 2, hh. 2794-2802.

DOI: 10.1016/j.sbspro.2010.03.417.

Majid, A 2013, Strategi Pembelajaran, Bandung, Rosdakarya.

Subagiyo, S 2019, 'Penerapan Model Blended Learning untuk Meningkatkan Pemahaman Konsep Termokimia Siswa', Journal of Education Chemistry, Vol. 1, No. 1, hh.1-8. DOI: http://dx.doi.org/10.21580/jec.2019.1.1.3830

Solihatin, Suana W, \& Sesunan F 2019, 'Pengaruh Pemanfaatan Mobile Instant Messaging (Mim) Pada Pembelajaran Materi Hukum Newton Terhadap Kemampuan Berpikir Tingkat Tinggi', Jurnal Ilmu Pendidikan, Vol. 15, No. 1, hh.1-10.

DOI: https://doi.org/10.32939/tarbawi.v15i1.349.

Weish, ET, Wanberg, CR, Brown, KG \& Simmering M.J 2003, 'E-learning: Emerging Uses, Empirical Results and Future Directions', International Journal of Training and Development, Vol. 7, No. 4, hh. 245-258. DOI: 10.1046/j.1360-3736.2003.00184.x 